top-shelf investigative journalism. Quickly after its broadcasting, board members of the Karolinska Institute, including the secretary-general of the Nobel Committee, had to resign and the paper on the regenerated synthetic trachea was retracted. ${ }^{15,16}$

This misleading story on tissue regeneration hasn't come to an end yet. Until now, other papers on the regenerated cadaver trachea still stay afloat. Synthetic tracheas and nonvascularized donor tracheas are destined to fail. They were wrongfully used for tracheal replacement and presented as breakthroughs in clinical tracheal tissue engineering.

\section{References}

1. Grillo HC. Tracheal replacement: a critical review. Ann Thorac Surg. 2002;73: 1995-2004.

2. Mercier O, Kolb F, Dartevelle PG. Autologous tracheal replacement: surgical technique and outcome. Thorac Surg Clin. 2018;28:347-55.

3. Wurtz A, Porte H, Conti M, Desbordes J, Copin MC, Azorin J, et al. Tracheal replacement with aortic allografts. $N$ Engl J Med. 2006;355:1938-40.

4. Rose KG, Sesterhenn K, Wustrow F. Tracheal allotransplantation in man. Lancet. 1979;1:433.

5. Levashov YN, Yablonsky PK, Cherny SM, Orlov SV, Shafirovsky BB, Kuznetzov IM. One stage allotransplantation of thoracic segment of the trachea in a patient with idiopathic fibrosing mediastinitis and marked tracheal stenosis. Eur J Cardiothorac Surg. 1993;7:383-6.
6. Delaere P, Vranckx J, Verleden G, De Leyn P, Van Raemdonck D. Leuven Tracheal Transplant Group. Tracheal allotransplantation after withdrawal of immunosuppressive therapy. N Engl J Med. 2010;362:138-45.

7. Macchiarini P, Jungebluth P, Go T, Asnaghi MA, Rees LE, Cogan TA, et al. Clin ical transplantation of a tissue-engineered airway. Lancet. 2008;372:2023-30.

8. Fux T, Österholm C, Themudo R, Simonson O, Grinnemo K-H, Corbascio M Synthetic tracheal grafts seeded with bone marrow cells fail to generate functional tracheae: first long-term follow-up study. J Thorac Cardiovasc Surg. 2020;159:2525-37.e23.

9. Fountain H. A first: organs tailor-made with body's own cells. The New York Times. September 15, 2012:A1. Available at: https://www.nytimes.com/2012/ 09/16/health/research/scientists-make-progress-in-tailor-made-organs.html. Accessed October 27, 2019.

10. Jungebluth P, Alici E, Baiguera S, Blomberg P, Bozóky B, Crowley C, et al. Tracheobronchial transplantation with a stem-cell-seeded bioartificial nanocomposite: a proof-of-concept study. Lancet. 2011;378:1997-2004.

11. Elliott MJ, De Coppi P, Speggiorin S, Roebuck D, Butler CR, Samuel E, et al, Stem-cell-based tissue engineered tracheal replacement in a child: a 2-year follow-up study. Lancet. 2012;380:994-1000.

12. The For Better Science blog, "Macchiarini's trachea transplant patients: the full list." Available at: https://forbetterscience.com/2017/06/16/macchiarinis-tracheatransplant-patients-the-full-list/. Accessed October 27, 2019.

13. Delaere PR, Van Raemdonck D. The trachea: the first tissue-engineered organ? J Thorac Cardiovasc Surg. 2014;147:1128-32.

14. Delaere P. Stem-cell "hype" in tracheal transplantation? Transplantation. 2010; 90:928-9.

15. The Lancet Editors. Retraction - Tracheobronchial transplantation with a stem-cellseeded bioartificial nanocomposite: a proof-of-concept study. Lancet. 2018;392:11. 16. Horton R. Offline: Paolo Macchiarini-science in conflict. Lancet. 2016;20:387.

\title{
Commentary: Trust but verify- How do we keep the faith?
}

Susan D. Moffatt-Bruce, MD, PhD, MBA, ${ }^{a}$ Thomas A. D'Amico, MD, ${ }^{\mathrm{b}}$ Richard D. Weisel, MD, ${ }^{\mathrm{c}}$ and Robert M. Sade, MD $^{\mathrm{d}}$

In this month's Journal, Fux and colleagues ${ }^{1}$ report the first long-term follow-up study of the outcome of synthetic

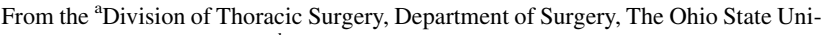
versity, Columbus, Ohio; ${ }^{\mathrm{b}}$ Section of General Thoracic Surgery, Duke University Medical Center, Durham, NC; ${ }^{\mathrm{c}}$ Toronto General Hospital and Research Institute, University of Toronto, Toronto, Ontario, Canada; and ${ }^{\mathrm{d}}$ Division of Cardiothoracic Surgery, Department of Surgery, Institute of Human Values in Health Care, Medical University of South Carolina, Charleston, SC.

Disclosures: Authors have nothing to disclose with regard to commercial support.

Received for publication Oct 19, 2019; revisions received Oct 19, 2019; accepted for publication Oct 21, 2019; available ahead of print Jan 8, 2020.

Address for reprints: Susan D. Moffatt-Bruce, MD, PhD, MBA, Division of Thoracic Surgery, Department of Surgery, 168 Doan Hall, 410 W 10th Ave, Columbus, OH 43210 (E-mail: Susan.moffatt-bruce@osumc.edu).

J Thorac Cardiovasc Surg 2020;159:2539-40

$0022-5223 / \$ 36.00$

Copyright (c) 2019 by The American Association for Thoracic Surgery

https://doi.org/10.1016/j.jtcvs.2019.10.113
}

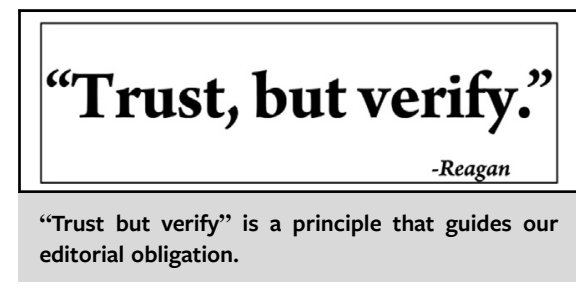

CENTRAL MESSAGE

Dissemination of innovation and
research is the raison d'être of
surgical journals; however, all
scientific findings must be
continually challenged and
questioned to ensure their
veracity.

tracheal grafts seeded with bone marrow cells at their institution. Their outcome data contradict previously reported successes with this technique. ${ }^{2-5}$ Fux and colleagues ${ }^{1}$ demonstrate that these grafts were not cellularized with site-specific cells and did not become living, functional 
grafts. The clinical use of the synthetic tracheal grafts led to substantial complications, suffering, and death in 3 patients who received 4 such grafts between 2011 and 2013 at their institution. Remarkably, 1 patient underwent 191 surgical reinterventions, including 57 airway stent interventions, and 7600 flexible bronchoscopies during an almost 5-year period that ultimately resulted in artificial life support and death when the patient was 25 years old. ${ }^{1}$ These findings are deeply disturbing, to say the least.

When a highly innovative salvage technology is introduced, patients and surgeons are often impatient and feel a moral obligation to use it. Synthetic trachea implantation is such a technology, yet neither scientific evidence nor long term clinical data are available to support the hypothesis that bone marrow mononuclear cells, when applied to a synthetic tube, produce a viable cellular layer that is able to function as clinically desired..$^{2-7}$

The publication of high-profile retractions came after the president of the Karolinska Institute and the Royal Swedish Academy of Sciences received information and expressions of concern around trial conduct and the ultimate conclusions of the studies. ${ }^{8,9}$ Paolo Macchiarini and his colleagues were found guilty of misconduct in the 2 Lancet articles that were ultimately retracted, and perhaps most disturbing were the findings of intentional deception and negligence in obtaining consent. ${ }^{8-10}$

The featured research article of Fux and colleagues ${ }^{1}$ in this issue of the Journal is important for the patients who suffered immensely from flawed research and for future patients who will be spared exposure to this underdeveloped technique. Does some responsibility to trust but verify the data and findings for such innovative yet high-stakes clinical conclusions lie with journal editors and reviewers? The enterprise of science is built on the expectation that reports of scientific experiments and clinical studies are truthful and reliable, yet journals must be sensitive to the possibility that misconduct taints the reported results. Uncovering fraud and other forms of misconduct depends on editorial alertness to data that seem questionable and sensitivity to allegations of colleagues who suspect transgression of research norms. ${ }^{11}$ An important responsibility of journal editors is to safeguard the veracity of the scientific literature, and we try to do that by insisting on rigorous peer review and setting a high standard for our reviewers. Even under the best policies and protocols, however, some fraud- ulent reports may be concealed well enough to elude detection, as was true of the Macchiarini episode for many years. Although the responsibility to investigate research misconduct, determine the facts of the case, and mete out appropriate penalties rests mainly with the institutions where the research was performed, journals and their reviewers and editors also must maintain vigilance and apply commensurate sanctions related to publication. When research misconduct is detected and confirmed, whether in prepublication stages or after publication, it is incumbent on editors to disseminate the information to other journals and scientific communities promptly, widely, and without bias.

"Trust but verify" is a principle that guides our editorial obligation to protect the integrity of the science we publish for our readers.

\section{References}

1. Fux T, Österholm C, Themudo R, Simonson O, Grinnemo K, Corbascio M. Synthetic tracheal grafts seeded with bone marrow cells fail to generate functional trachea: first long-term follow-up study. J Thorac Cardiovasc Surg. 2020;159: 2525-37.e23.

2. Jungebluth P, Alici E, Baiguera S, Blomberg P, Bozóky B, Crowley C, et al. Tracheobronchial transplantation with a stem-cell-seeded bioartificial nanoartificial nanocomposite: a proof-of-concept study. Lancet. 2011;378:1997-2004. Erratum in: Lancet. 2016;387:1276. Erratum in: Lancet. 2016 Apr 2;387(10026):1376. Erratum in: Lancet. 2016;387:944. Retraction in: Lancet. 2018;392:11.

3. Badylak SF, Weiss DJ, Caplan A, Macchiarini P. Engineered whole organs and complex tissues. Lancet. 2012;379:943-52. Retraction in: Lancet. 2018;392:11.

4. Jungebluth P, Haag JC, Lim ML, Lemon G, Sjöqvist S, Gustafsson Y, et al. Verification of cell viability in bioengineered tissues and organs before clinical transplantation. Biomaterials. 2013;34:4057-67. Retraction in: Biomaterials. 2019;199:88.

5. Del Gaudio C, Baiguera S, Ajalloueian F, Bianco A, Macchiarini P. Are synthetic scaffolds suitable for the development of clinical tissue-engineered tubular organs? J Biomed Mater Res A. 2014;147:1128-32. Retraction in: J Biomed Mater Res A. 2018;106:2581.

6. Udelsman B, Mathisen DJ, Ott HC. A reassessment of tracheal substitutes-a systematic review. Ann Cardiothorac Surg. 2018;7:175-82.

7. Jungebluth P, Haag JC, Sjöqvist S, Gustafsson Y, Beltrán Rodríguez A, Del Gaudio C, et al. Tracheal tissue engineering in rats. Nat Protoc. 2014;9:2164-79.

8. Claesson-Welsh L, Hansson GK; Royal Swedish Academy of Sciences. Tracheobronchial transplantation: the Royal Swedish Academy of Sciences' concerns. Lancet. 2016;387:942.

9. The Lancet. The final verdict on Paolo Macchiarini: guilty of misconduct. Lancet. 2018;392:2.

10. The Lancet Editors. Retraction-tracheobronchial transplantation with a stemcell-seeded bioartificial nanocomposite: a proof-of-concept study. Lancet. 2018;392:11.

11. Edelstein L. The Hippocratic Oath: Text, Translation and Interpretation. Baltimore: The Johns Hopkins Press; 1943. 